The BMJ

richardson@bmj.com

Cite this as: BMJ 2020;371:m4582 http://dx.doi.org/10.1136/bmj.m4582 Published: 14 December 2020
CHRISTMAS 2020: DR WHO?

\section{The doctors who time forgot}

After SARS-CoV-2 belatedly highlighted the work of the virologist June Almeida, who first imaged a human coronavirus in the 1960s, ${ }^{1}$ historians reveal some of medicine's other forgotten figures

Jennifer Richardson features editor

\section{Phyllis Kerridge (1901-1940)}

Phyllis Kerridge was a British chemist and physiologist whose scientific research significantly transformed medical perceptions of disability. A leader in her field, an inventor, and a physician, she inspired further work in telephony, audiometry, and physiology-breaking gender barriers and fostering collaborations around the world.

Kerridge campaigned for better hearing aid provision and social reform, working with social organisations to lower the cost of hearing devices to make them more accessible for all users. She spent her career establishing quantitative studies on hearing acuity, laying the groundwork for laboratory practice and clinical acumen for audiometric tests that would eventually become standard post-war practice. Her survey on hearing acuity in children in London County Council schools did much to assess the importance of preventive deafness-a topic that was steadily gaining urgency in medical deafness, especially given the high numbers of war deafened ex-servicemen relying on state welfare. She even collaborated with the General Post Office to improve its telephones for deaf people.

Kerridge was critical in perfecting the design of the Bragg-Paul Pulsator, an artificial respirator: she made the device workable, replicable, and usable by children. She promoted and advertised the device to hospitals and argued with the Ministry of Health that the Pulsator should be implemented as standard hospital technology. She pressured the minister of health to incorporate artificial respirators in all English hospitals to combat polio and diphtheria outbreaks and to save the lives of patients in respiratory distress.

\section{Nominated by}

Coreen McGuire: lecturer, University of Durham, UK

Jaipreet Virdi: assistant professor, University of Delaware, USA

\section{Matthew Baillie (1761-1823)}

As a prominent physician who was a founder member and second president of the Medical and Chirurgical Society (now the Royal Society of Medicine), as well as being physician extraordinary to George III and memorialised in Westminster Abbey, Matthew Baillie might not seem an obvious candidate for this list. But not only has he been thoroughly overshadowed by his uncles, John and William Hunter of the Hunterian museums (plural), his fundamental importance to the history of pathology has largely been forgotten.

His most important and popular work, The Morbid Anatomy of Some of the Most Important Parts of the Human Body (1793), and its related illustrations, transformed the study of disease in Britain. Disease had been studied through cases, but Baillie promoted an anatomical approach underpinned by collecting pathological specimens on a large scale. The careful study and description of the structures and textures of how the body was changed by disease, and their illustration, boomed in early 19th century Britain: morbid anatomies of the brain, the stomach and bowels, the liver, uterus, and serous and mucous membranes were all published in Britain by 1840 .

Admirers included Edward Jenner, who contributed specimens to Baillie's collection, and René Laennec, who sent Baillie a copy of his book on the stethoscope along with a gushing note. Moreover, his work clearly influenced that of more famous pathologists such as Thomas Hodgkin and Richard Bright. So, although not unremembered, Baillie is certainly

misremembered, and he ought to have a more prominent place in the history of British medicine.

\section{Nominated by}

Richard T Bellis: senior research associate, Bristol Medical School, University of Bristol, UK

\section{Edith Brown (1864-1956)}

Edith Brown founded the first medical school for women in South East Asia. Her own training at the London School of Medicine for Women was sponsored by the Baptist Mission Society, and just weeks after qualifying in 1891 she was bound for India.

At a time when routes for women into professional medicine were hugely restricted, Brown set out to train doctors, nurses, and midwives from India's Christian communities. To that end, in 1894 she established the North India School of Medicine for Christian Women in Ludhiana, Punjab, with 16 students. Significantly, the enterprise attracted broad support from far beyond the Christian community. Since instruction was given in multiple languages, entry was also possible for students from a wide range of social and economic backgrounds. By 1899 Brown Asul, in Urdu. This became a standard reference text throughout India, and she continued in her role as principal of the school until her retirement in 1942. By then the school had awarded diplomas to 411 herself published a midwifery textbook, Daigiri Ke 
doctors, 143 nurses, 168 dispensers, and more than 1000 midwives. The school still operates today as the Christian Medical College and Hospital in Ludhiana, a remarkable legacy of medical training and treatment. In a period of Indian history so tainted by British imperialism, it's no small feat that Brown's Christian medical college was welcomed so comprehensively across broad social and religious divisions. Although she was recognised with a damehood in 1932, her important contributions are now largely forgotten.

\section{Nominated by}

James Stark: director, Leeds Arts and Humanities Research Institute; professor of medical humanities, University of Leeds, UK

\section{Tolani Asuni (1924-2011)}

Tolani Asuni was Nigeria's second indigenous psychiatrist. As a pioneer of psychiatry in Africa, he was always overshadowed by the international recognition accorded his contemporary, Thomas Adeoye Lambo. Yet Asuni's work in many ways had a more practical and wider reaching impact on the discipline across the African continent.

Asuni broke new ground in research on mental health. He was one of Africa's first suicidologists, also providing empirical data on homicide that helped shape the continent's development of criminology. In the early 1970 , he was a rare voice internationally in warning that refugees' mental health would soon become a major public health issue in Africa.

Always concerned with direct change, he championed reducing the stigma against people who attempt suicide, rehabilitation services for mentally ill homeless people, and national research and training programmes for people affected by substance misuse. Finally, Asuni will have shaped the minds of countless undergraduate and postgraduate medical students: his Mental Health and Disease in Africa (1975), co-written with Charles Swift, was the only regionally focused textbook on psychiatry for over 30 years.

\section{Nominated by}

Oyedeji Ayonrinde: associate professor, Queen's University, Canada

Yolana Pringle: senior lecturer, University of Roehampton, UK

\section{Jacques Azoulay (1927-2011)}

Jacques Azoulay was a Jewish-Algerian psychiatrist and psychoanalyst who, with Frantz Fanon, first incorporated local conceptualisations of mental illness into treatments for Muslim patients.

Born in 1927 in Algiers into a middle class, non-Arabic speaking family, he was directly affected by the antisemitic laws of Vichy France. While studying at the Medical Faculty in Algiers, he started working as an intern in the Psychiatric Hospital of Blida-Joinville under Fanon in 1953. He described measures introduced under Fanon in his 1954 dissertation on "Sociotherapy among Algerian mental patients," based on the French theory of institutional psychotherapy.

In 1954 a chapter of Azoulay's dissertation was slightly modified and turned into an article that he co-wrote with Fanon, entitled "Sociotherapy on a Muslim men's ward," in which they described adapting a "revolutionary attitude" towards their Muslim patients and advocated "cultural relativism," in direct contrast to the racist theories of the dominant École d'Alger under Antoine Porot. They researched local explanations for mental illness, as well as the damaging influence of colonialism on the mental states of colonised people. They tried to incorporate local customs into the psychiatric institutions, introducing, among other things, the celebration of traditional holidays and a "Moorish Café" in Blida-Joinville.

Azoulay also composed two unpublished articles in 1954: one with Fanon on "Daily life in the Douars" and one with Fanon and François Sanchez, entitled "Introduction to sexual disorders among north Africans."

\section{Nominated by}

Nina S Studer: postdoctoral researcher at the University of Bern, Switzerland

\section{A notable patient activist: Neville Clare (1946-2015)}

Neville Clare was a health activist who advocated for people with the genetic condition sickle cell disease (SCD), a haemoglobin disorder found mostly in people descended from Africa and south Asia.

Born in Jamaica, he came to Britain aged 11 and had a form of SCD diagnosed in 1967, but he found that his doctors had little understanding of his illness. Embedded in the radical politics and Black consciousness movements of the 1960 s and '7os, Clare founded the Organisation for Sickle Cell Anaemia Research (OSCAR) in London in 1975-the first voluntary organisation in the UK dedicated to the condition.

OSCAR worked to liaise with doctors, produce educational material, raise awareness about SCD in Black communities, and support people with SCD. This work was highly challenging at a time when right wing groups such as the National Front used SCD in virulent racist propaganda, and Clare spoke at community meetings and medical symposiums around in Britain, hoping to counter some of the stigma surrounding SCD.

Other branches of OSCAR were subsequently established in Sandwell, Nottingham, Dudley, Bristol, Reading, Croydon, and Leicester, many still existing today and representing the interests of people with SCD to local services. Clare's work was a blueprint for local SCD support groups, and he remained a passionate advocate for people with the condition until his death in 2015.

Nominated by

Grace Redhead: postdoctoral researcher, Centre for the History of Medicine, Department of History, University of Warwick, UK

Competing interests: None declared.

Provenance and peer review: Commissioned, not peer reviewed.

Mahase E. Covid-19: Coronavirus was first described in The BM/ in 1965. BM/2020;369:m1547. doi: 10.1136/bmj.m1547 pmid: 32299810 